\title{
MELIOLACEAE OF KERALA, INDIA - XIV
}

\author{
V.B. Hosagoudar \\ Microbiology Division, Tropical Botanic Garden and Research Insitute, Palode, Thiruvananthapuram, Kerala 695562, India.
}

\begin{abstract}
This paper gives an account of five taxa of Meliolaceae. Of these, Asteridiella kombeensis and Meliola dysoxylimalabarici are new species; Meliola aethiops var. keralica and M. hydnocarpi var. indica are new varieties, while Meliola castlerockensis is synonymised with M. cookeana var. viticis.
\end{abstract}

\section{Keywords}

Fungi, Asteridiella, Meliola, Kerala, new description

\begin{abstract}
Abbreviations
HCIO - Herbarium Cryptogamae Indiae Orientalis, New Delhi

TBGT - Tropical Botanic Garden, Thiruvananthapuram
\end{abstract}

\section{Introduction}

Meliolaceous fungi are commonly called black mildews. These are ectophytic obligate parasites, infecting mainly leaves, rarely petioles and tender stems. These fungi constitute one of the largest group of fungi represented with nine genera and 2200 species in the world (Hansford, 1961; Hosagoudar et al., 1997). However, still they are very little known to mycologists probably due to lack of systematic survey of these fungi in the tropics and also due to diminishing taxonomic work. Contrary to it, their abundance in the southern Western Ghats in Peninsular India has attracted attention and has resulted in the continuing work since more than two decades (Hosagoudar, 1996; Hosagoudar et al., 1997, 1998a,b,c,d, 1999, 2000a,b, 2001).

\section{Materials and Methods}

For microscopic studies, scrapes from selected colonies were mounted in $10 \% \mathrm{KOH}$ solution. After 10 minutes, $\mathrm{KOH}$ was replaced by Lactophenol. Both mountants clear melanin pigments and make the septa visible. However, to prepare permanent slides, a drop of transparent nail polish was applied to the selected colonies, thinned carefully and allowed to dry for 10-20 minutes in a dust free chamber. After ensuring dryness, with the help of a blade the dried flip along with the embedded colonies were pealed off, and spread with a drop of D.P.X. mountant on a clean glass slide. A cover glass was placed over it carefully to prevent air bubbles after adding another drop of D.P.X. on the flip. These slides were used for further study after ensuring their dryness in a day or two.

\section{Asteridiella kombeenisis sp. nov.}

(Figs. 1-3)

Coloniae epiphyllae, densae, ad $3 \mathrm{~mm}$ diameter, raro confluentes, Hyphae subrectae, flexuosae vel raro anfractuae, alternate vel opposite acuteque vel laxe ramosae, laxe vel arcte

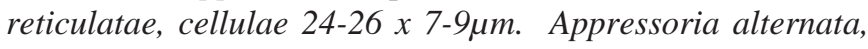
recta vel uncinata, antrorsa, subantrorsa vel retrorsa, 24-28 $\mu \mathrm{m}$

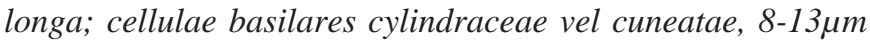
longae; cellulae apicales ovatae, globosae, integrae,

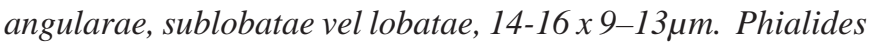
appressoriis intermixtae, alternatae, oppositae vel

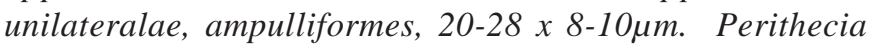
dispersa, globosa, ad $175 \mu \mathrm{m}$ diameter; celluae peritheciales indistinctae; ascosporae oblongae, raro ellipsoideae, quadra septatae, constrictae, 33-40 x 14-18 $\mu \mathrm{m}$.

Colonies epiphyllous, dense, up to $3 \mathrm{~mm}$ in diameter, rarely confluent. Hyphae substraight, flexuous to rarely crooked, branching alternate to opposite at acute to wide angles, loosely 

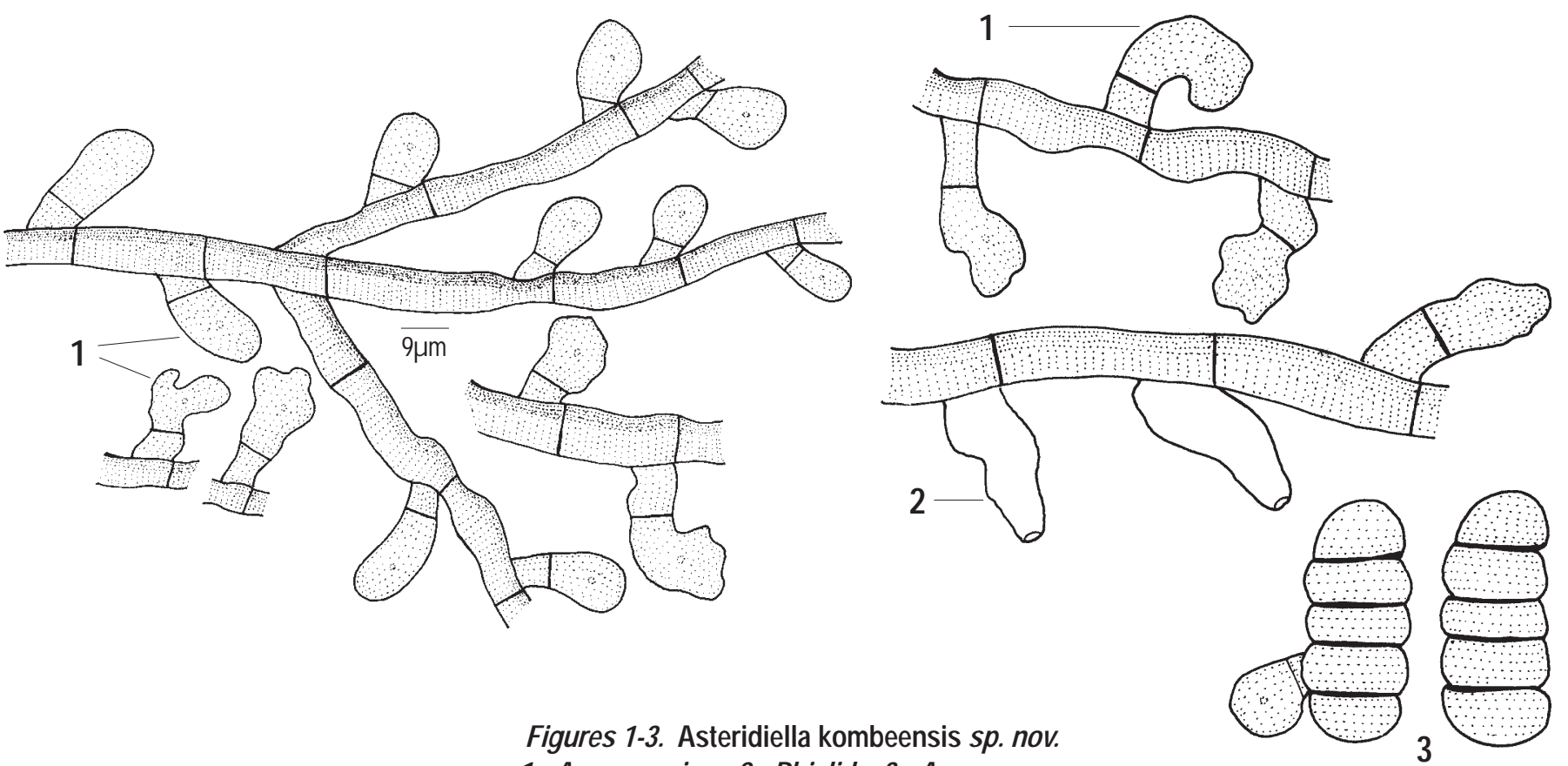

Figures 1-3. Asteridiella kombeensis sp. nov.

1 - Appressorium, 2 - Phialide, 3 - Ascospores.
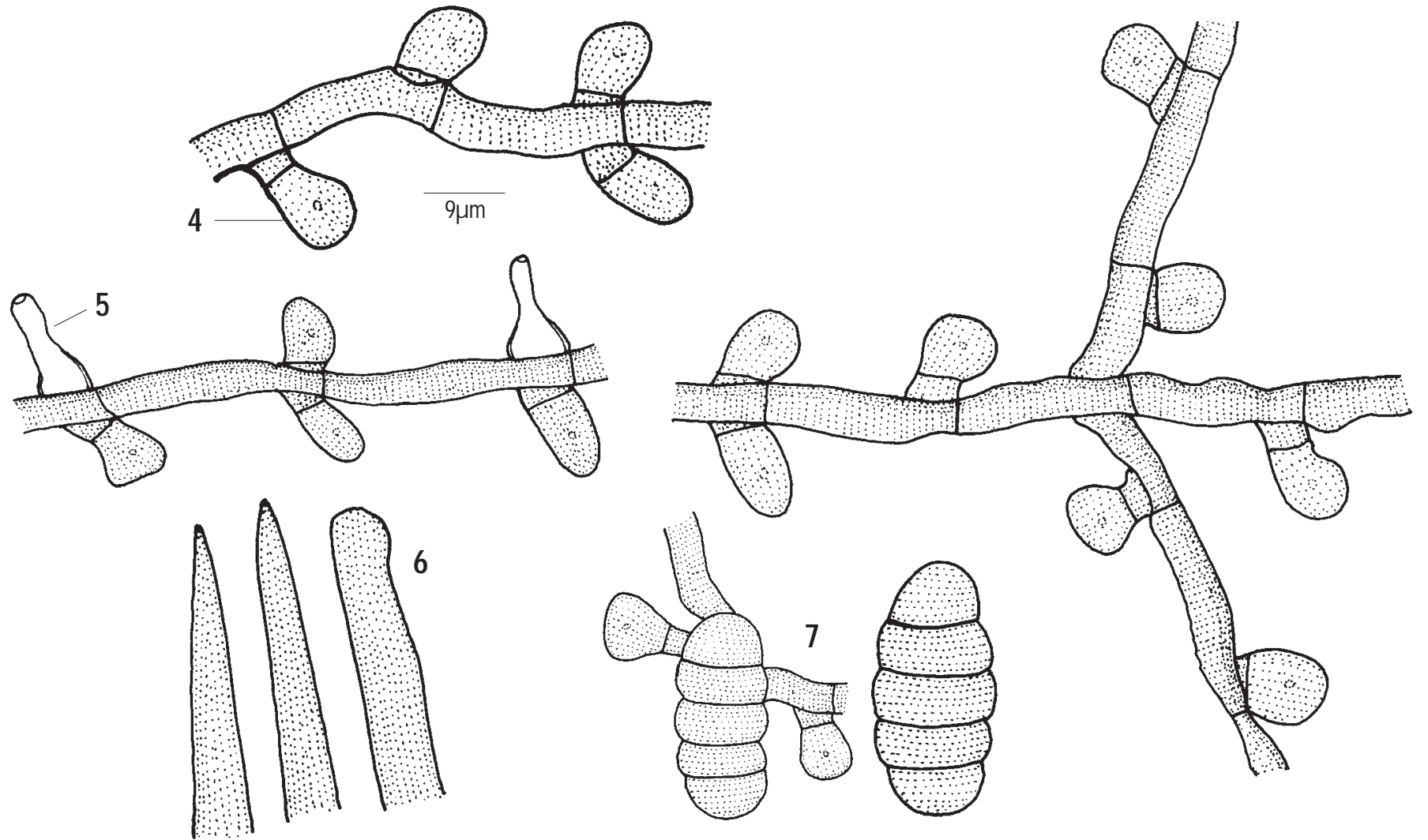

Figure 4-7. Meliola aethiops Sacc. var. keralica var. nov. 4 - Appressorium, 5 - Phialidae, 6 - Mycelial setae, 7 - Ascospores (one germinated) 
to closely reticulate, cells $24-26$ x 7-9 $\mu \mathrm{m}$. Appressoria alternate, straight to uncinate, antrorse, subantrorse to retrorse, $24-28 \mu \mathrm{m}$ long; stalk cells cylindrical to cuneate, $8-13 \mu \mathrm{m}$ long; head cells ovate, globose, entire angular, sublobate to lobate, 14-16 x 9$13 \mu \mathrm{m}$. Phialides mixed with appressoria, alternate, opposite to unilateral, ampulliform, 20-28 x 8-10 $\mu \mathrm{m}$. Perithecia scattered, globose, up to $175 \mu \mathrm{m}$ in diameter; perithecial wall cells indistinct; ascospopres oblong, rarely ellipsoidal, 4-septate, constricted, $33-40$ x 14-18 $\mu \mathrm{m}$.

\section{Material examined}

Holotype: On leaves of Mallotus philippensis (Lam.) Muell. Arg. (Euphorbiaceae), Kombe, Peppara and Neyyar Wildlife Sanctuaries, Thiruvananthapuram, Kerala, India, 9.iii.1996, V.B. Hosagoudar, HCIO 44206.

Isotype: TBGT 563.

\section{Remarks}

According to Beeli formula (3101. 3220), this species is close to Asteridiella hansfordii (Stev.) Hansf. but differs from it having antrorse to spreading appressoria with predominantly entire to sublobate head cells (Hansford, 1961). This material was severely infected with synnematous Spiropes sp.

\section{Meliola aethiops Sacc. var. keralica var. nov. (Figs. 4-7)}

Differt a var. aethiops appressoria $15 \%$ opposita, setae myceliales longiorae et ascosporae magniorae.

Colonies epiphyllous, thin to subdense, up to $3 \mathrm{~mm}$ in diameter, rarely confluent. Hyphae substraight to flexuous, branching mostly opposite at acute to wide angles, loosely to closely reticulate, cells 20-26 x 4-6.5 $\mu \mathrm{m}$. Appressoria alternate, about $15 \%$ opposite, antrorse to subantrorse, slightly recurved, 11$15 \mu \mathrm{m}$ long; stalk cells cylindrical to cuneate, $3-4 \mu \mathrm{m}$ long; head cells ovate to globose, straight to slightly curved, entire, $8-11 \mathrm{x}$ $8-10 \mu \mathrm{m}$. Phialides mixed with appressoria, alternate to opposite, ampulliform, 16-20 x 6-8 $\mu \mathrm{m}$. Mycelial setae few, grouped around perithecia, simple, straight to slightly flexuous, acute to obtuse at the tip, up to $350 \mu \mathrm{m}$ long. Perithecia globose, up to $112 \mu \mathrm{m}$ in diameter; ascospores oblong to cylindrical, 4-septate, constricted at the septa, 32-40 x 12-16 $\mu \mathrm{m}$.

\section{Material examined}

Holotype: On leaves of Cassia sp. (Mimosaceae), Kombe, Peppara and Neyyar Wildlife sanctuary, Thiruvananthapuram, Kerala, India, 25.ii.1997, V.B. Hosagoudar, HCIO 44183. Isotype: TBGT 561.

\section{Remarks}

Based on the Beeli formula 3113.3222 and epiphyllous thin colonies, the present collection is similar to Meliola aethiops Sacc. var. minor Hansf. \& Deight. known on Cassia siamea from Africa (Hansford, 1961). However, the new variety differs from it in having $15 \%$ opposite appressoria, longer mycelial setae and larger ascospores.

\section{Meliola dysoxyli-malabarici V.B. Hosagoudar et M. Kamarudeen, sp. nov.} (Fig. 8-11)

Coloniae hypophyllae, subdensae, ad $2 \mathrm{~mm}$ diameter, confluentes. Hyphae subrectae, irregulariter acuteque vel laxe ramosae, laxe vel dense reticulatae, cellulae 22-26 x 4-5 Appressoria alternata, unilateralia, ad $30 \%$ opposita, antrorsa, subantrorsa vel leniter retrorsa, 11-16 $\mu$ m longa; cellulae basilares cylindraceae vel cuneatae, 2-5 cellulae apicales ovatae, integrae, rectae vel leniter recurvae,

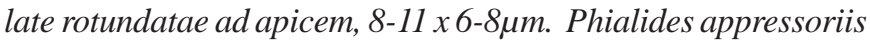
intermixtae, alternatae vel oppositae, ampulliformes, 16-18 $x$ 6-8 $4 \mathrm{~m}$. Setae myceliales dimorphae; setae myceliales simplices

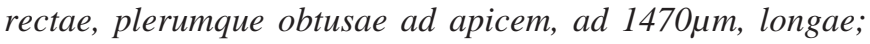
setae circa peritheciales simplices, rectae, curvulae, uncinatae,

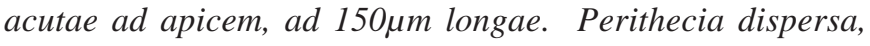
globosa, ad 175 um diameter; ascosporae obovoidae, quadra septatae, constrictae, 30-32 × 12-16 $\mu \mathrm{m}$.

Colonies hypophyllous, subdense, up to $2 \mathrm{~mm}$ in diameter, confluent. Hyphae substraight, branching irregular at acute to wide angles, loosely to closely reticulate, cells $22-26$ x 4-5 $\mu \mathrm{m}$. Appressoria alternate, unilateral, about $30 \%$ opposite, antrorse, subantrorse to slightly retrorse, $11-16 \mu \mathrm{m}$ long; stalk cells cylindrical to cuneate, $2-5 \mu \mathrm{m}$ long; head cells ovate, entire, straight to slightly recurved, broadly rounded at the apex, 8-11 x 6-8 $\mu \mathrm{m}$. Philalides mixed with appressoria, alternate to opposite, ampulliform, 16-18 x 6-8 $\mu \mathrm{m}$. Mycelial setae two types: setae on mycelia are scattered, simple, straight, mostly obtuse at the tip, up to $1470 \mu \mathrm{m}$ long; setae grouped around perithecia are simple, straight, curved, uncinate, acute at the tip, up to $150 \mu \mathrm{m}$ long. Perithecia scattered, globose, up to $175 \mu \mathrm{m}$ in diameter, ascospores obovoidal, 4-septate, constricted at the septa, 30-32 x 12-16 $\mu \mathrm{m}$.

\section{Material examined}

Holotype: on leaves of Dysoxylum malabaricum Bedd. ex Hiern (Melilaceae), Manjakuzhi, Kulamavu, Idukki, Kerala, India, 5.ix.2001, M. Kamarudeen, HCIO 44202.

Isotype: TBGT 565.

\section{Remarks}

Based on the uncinate mycelial setae, the present species is closer to Meliola obvallata Sysow and M. dysoxyli-nitidi Huguenin var. minor Huguenin (Hansford, 1961; Huguenin, 1969; 


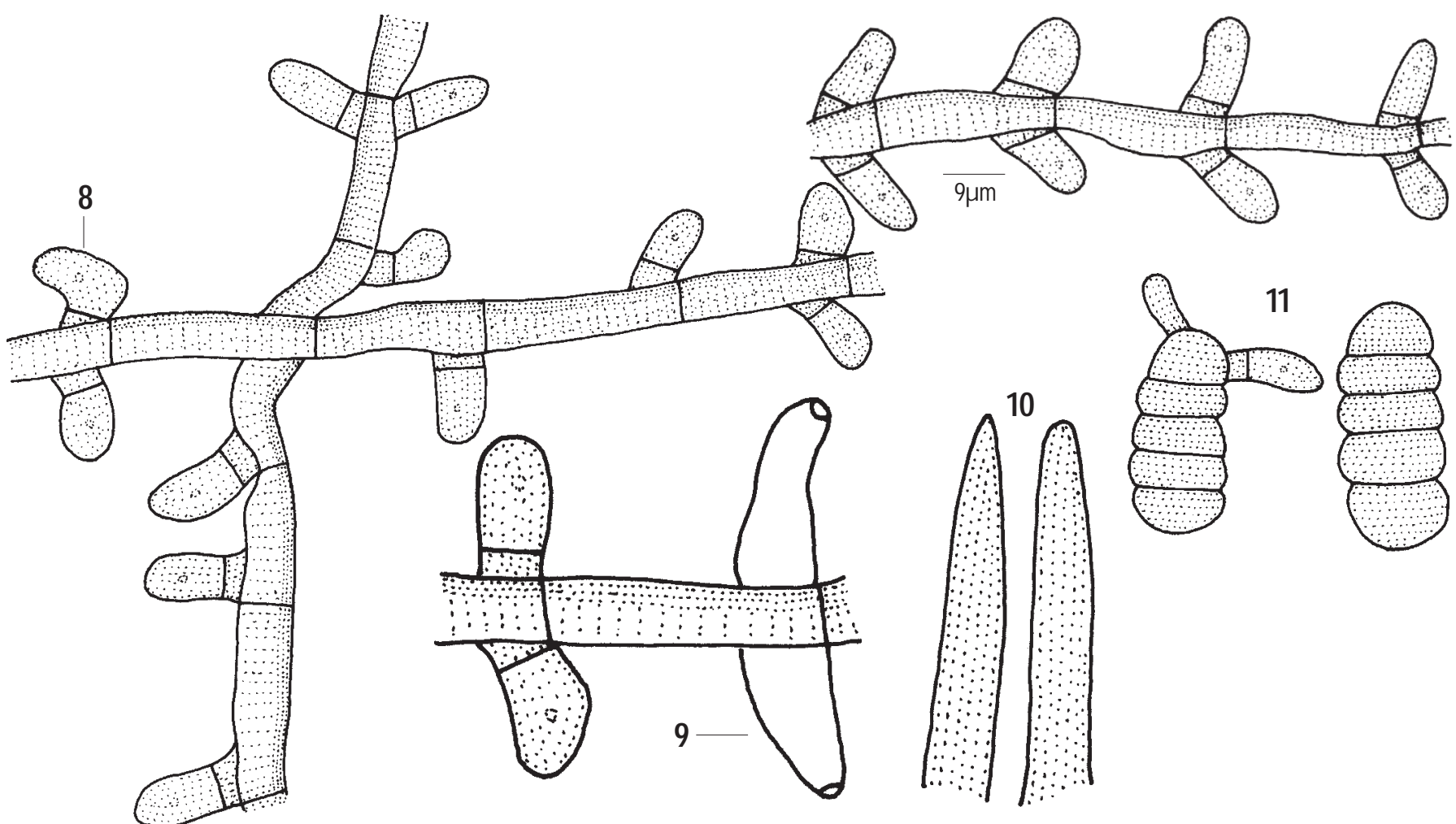

Figure 8-11. Meliola dysoxyli-malabarica sp. nov.

8 - Appressorium, 9 - Phialide, 10 - Mycelial setae, 11 - Ascospores (one germinating)

Hosagoudar et al. 1997) but differs from both in having two types and longer mycelial setae.

\section{Meliols hydnocarpi Hansf. var. indica V.B. Hosagoudar et M. Kamarudeen, var. nov.}

(Figs. 12-15)

Differt a var. hydnocarpi, coloniae hypophyllae, densae, setae myceliales $1 \%$ unicinatae et ad apicem acutae.

Colonies hypopyllous, dense, velvety, up to $3 \mathrm{~mm}$ in diameter, rarely confluent. Hyphae substraight to crooked, branching irregular at acute to wide angles, loosely to closely reticulate, cells $25-35$ x 6-7 $\mu \mathrm{m}$. Appressoria alternate, about $2 \%$ opposite, antrorse to subantrorse, straight to curved, 14-18 $\mu \mathrm{m}$ long; stalk cells cylindrical to cuneate, $4-6.5 \mu \mathrm{m}$ long; head cells ovate to globose, straight to curved, entire to rarely angular, 9-11 x 7$9 \mu \mathrm{m}$. Mycelial setae densely scattered on the colonies, simple, straight, rarely about $1 \%$ uncinate, acute at the tip, up to $350 \mu \mathrm{m}$ long. Perithecia scattered, globose, up to $163 \mu \mathrm{m}$ in diameter; ascospores oblong to cylindrical, 4-septate, constricted at the septa, 36-40 x 12-15 $\mu \mathrm{m}$.

\section{Material examined}

Holotype: On leaves of Hydnocarpus pentandra (Buch-Ham) Oken (Flacourtiaceae), Idukki, Kerala, India, 6.ix.2001, M. Kamarudeen, HCIO 44199.

Isotype: TBGT 564.

\section{Remarks}

The present collection can be compared with Meliola hydnocarpi Hansf. known on Hydnocarpus hutchinsonii from British North Borneo (Hansford, 1961). However, the new variety differs from the var. hydnocarpi in having hypophyllous dense colonies, $1 \%$ uncinate mycelial setae and all with acute tips.

\section{Meliola cookeana Speg. var. viticis Hansf., Sydowia Beih. 2: 690, 1961}

=Meliola castlerockensis Srinivasulu, Nova Hedwigia Beih. 47: $425,1974$.

The protologue of Meliola castlerockensis Srinivasulu matches well with that of M. cookeana Speg. var. viticis Hansf. known on the same host from Java. Further, Hosagoudar et al. (1998) have recorded this fungus on the same host from the southern 


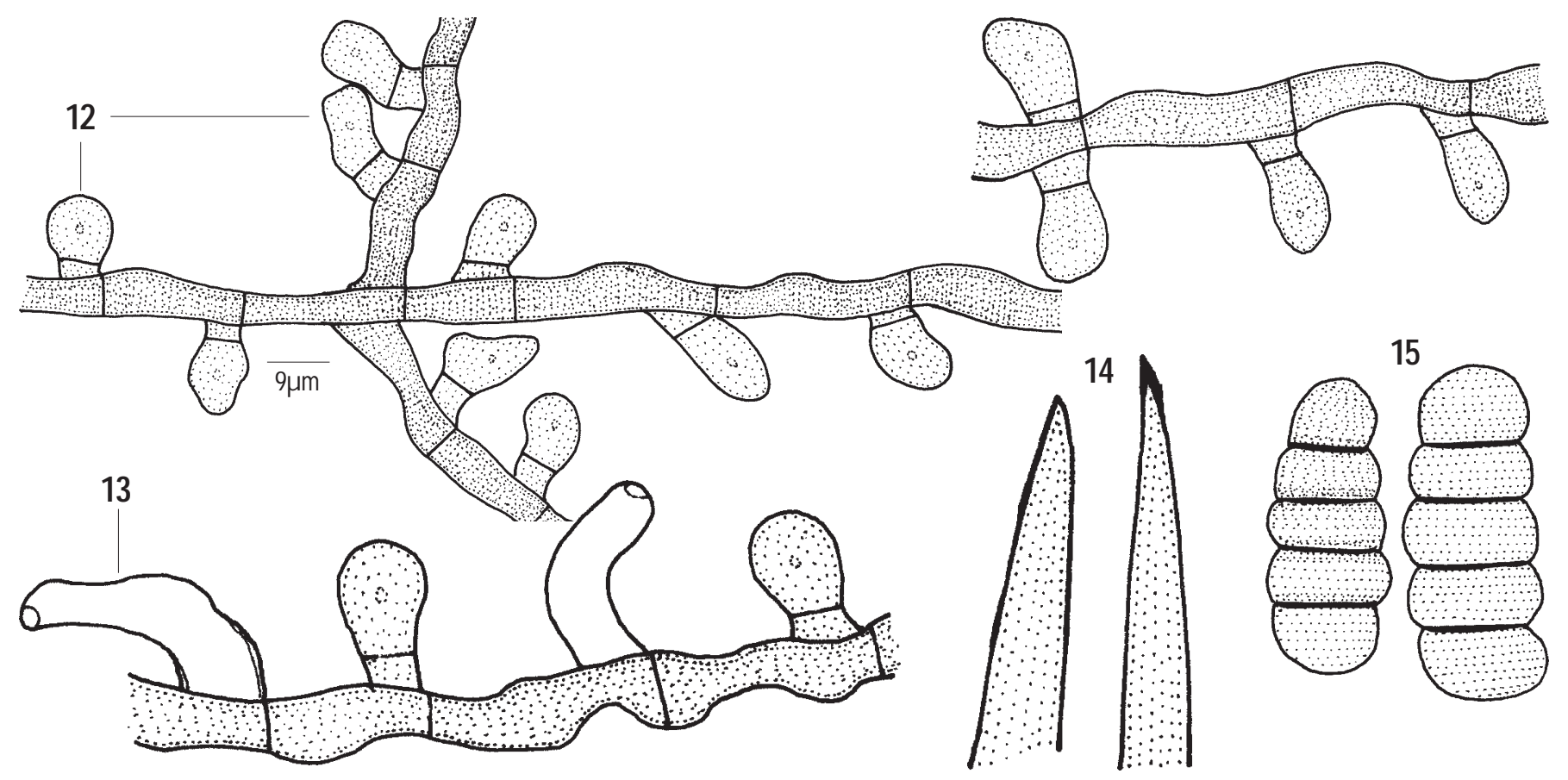

Figure 12-15 Meliola hydnocarpi Hansf. var. indica var. nov. 12 - Appressorium, 13 - Phialide, 14 -Mycelial setae, 15 - Ascospores.

Western Ghats. Hence, Meliola castlerockensis Srinivasulu (1974) has been made synonymous.

\section{Discussion}

These fungi flourish well in the Western Ghats of Penisnsular India. Records reveal their presence in the Eastern Ghats. However, few are known from the Himalayan region. Hence, the systematic survey of these in all regions of India will reveal an astonishing number of these fungi.

The biology, cytology, developmental aspects of these fungi are little known or meagre. The colony growth is very slow, ascospores cannot be successfully germinated in vitro or in vivo.

Little study has been carried out regarding their host-pathogen association and biochemical analysis of the host plants. However, the utilitarian aspect is yet to be attempted.

\section{Acknowledgement}

Thanks are due to Dr. G.M. Nair, Director, TBGRI, Palode for the facilities

\section{References}

Hansford, C.G. (1961). The Meliolineae. A Monograph. Sydowia Beihefte. 2: 1-806.
Hosagoudar, V.B. (1996). Meliolales of India. Botanical Survey of India, Calcutta, pp. 363.

Hosagoudar, V.B., T.K. Abraham and R.D. Goos (1997). Three new species of the Meliolaceae from Kerala, India. Mycotaxon 63: 493-496. Hosagoudar, V.B., T.K. Abraham and P. Pushpangadan (1997). The Meliolineae. A Supplement. TBGRI, Palode, pp. 201.

Hosagoudar, V.B., T.K. Abraham and J.L. Crane (1998). Meliolaceae of Kerala, India - V. Mycotaxon 69: 391-397.

Hosagoudar, V.B., T.K. Abraham and J.L. Crane (1999). Meliolaceae of Kerala, India - VI. Mycotaxon 71: 149-153.

Hosagoudar, V.B., T.K. Abraham and R.D. Goos (1998a). Meliolaceae from Kerala, India - II. Mycotaxon 64: 103-107.

Hosagoudar, V.B., T.K. Abraham and R.D. Goos (1998b). Meliolaceae from Kerala, India - III. Mycotaxon 66: 109-113.

Hosagoudar, V.B., T.K. Abraham and R.D. Goos (1998c). Meliolaceae from Kerala, India - IV. Mycotaxon 66: 115-119.

Hosagoudar, V.B., C.K. Biju, T.K. Abraham and J.L. Crane (2000). Meliolaceae from Kerala, India - VII. Mycotaxon 76: 299-304.

Hosagoudar, V.B., C.K. Biju and T.K.Abraham (2000). Meliolaceae from Kerala, India - VIII. Journal of Economic and Taxonomic Botany, 24: 474-480.

Hosagoudar, V.B., C.K. Biju and T.K. Abraham (2001). Meliolacea from Kerala, India - X. Journal of Economic and Taxonomic Botany, 25: 68-73.

Huguenin, B. (1969). Micromycetes du Pacifique Sud VII. Meliolinees de Nouvelle- Caledonie. Revue de Mycologie, Tome 34: 4-61.

Srinivasulu, B.V. (1974). Genus Meliola from Maharashtra State. Nova Hedwigia 47: 421-437. 